\title{
女子大学生の食事摂取パターンの類型化と関連要因の検討
}

高木 亜里紗, 戸田 雅裕, 池川 明里

ノートルダム清心女子大学大学院人間生活学研究科

\section{Dietary Patterns and Related Factors among Female University Students}

\author{
Arisa TAKAGI, Masahiro TODA and Akari IKEGAWA \\ Graduate School of Human Life Sciences, Notre Dame Seishin University
}

\begin{abstract}
Objectives: To investigate the associations between dietary patterns and mental health status of female university students.

Methods: Self-administered questionnaires consisting of measures of food intake frequency and mental health status were completed by 320 female university students. Food intake frequency was assessed using the Food Frequency Questionnaire (FFQ). Then, dietary patterns were identified by cluster analysis. The 28-item General Health Questionnaire (GHQ-28) was used to evaluate students' mental health status. Relationships between the dietary patterns and the mental health status were analyzed.

Results: We identified three dietary patterns. "The Japanese foods pattern in youth" was a representative food intake pattern of this generation. "The light eating pattern" had lower intakes of most items but higher intakes of soft drinks, and was not interested in nutrition balance. "The dairy products pattern" had higher intakes of dairy products and sweets, and were significantly associated with high scores of GHQ-28 subscale anxiety and insomnia.
\end{abstract}

Conclusion: The dietary patterns are associated with the mental health status of female university students.

Key words: dietary pattern（食事摂取パターン）, mental health status（精神的健康度）, dietary habit（食習慣），Food Frequency Questionnaire（食物摂取頻度調査）, 28-item General Health Questionnaire (GHQ-28)

緒言

平成 28 年「国民健康・栄養調査」において, 主食・ 主菜・副菜を組み合わせた食事は若い世代活ど食べられ ていない傾向にあり，外食や中食の利用割合が高いこと が報告されている。特に $20 \sim 30$ 歳代の女性では，たん ぱく質, カルシウム, 食物繊維及びカリウムなどの摂取 量が，60歳以上に比べて少ない傾向にあるとされ (1), 青年期の食生活の乱れによる摂取栄養素の偏りが問題と なっている。

平成 28 年国民生活基礎調查では，気分障害・不安障

受付 2018 年 6 月 29 日, 受理 2018 年 9 月 28 日 Reprint requests to: Masahiro TODA

Graduate School of Human Life Sciences, Notre Dame Seishin University, 2-16-9 Ifuku-cho, Kita-ku, Okayama 700-8516, Japan TEL: +81(86)252-2199, FAX: +81(86)-252-2196

E-mail: mt@post.ndsu.ac.jp
害に相当する心理的苦痛を感じている者は 20 歳以上で 10.5\% となっており，その割合の減少が「健康日本 $21 」$ の目標として掲げられている。また日常生活での悩みや ストレスがある者の割合は，20～ 29 歳で男性 43.6\%, 女性 $53.1 \%$ となって打り (2)，青年期の約半数が悩みや ストレスを抱えている状況にある。

一般的な精神障害が初めに現れるのは，幼少期及び青 年期であるとされており（3），オーストラリアとノル ウェ一の先行研究に招いて，幼少期と青年期で不健康 な食事パターンと良くない精神的健康状態との間に有 意な関連がみられたことや (4), 日本の中・高・大学生 に扣いて, 肉類, 牛乳・乳製品, 野菜類の低摂取頻度 群が高摂取頻度群に比べ，精神的健康度が低いことが 報告されている (5)。青年期はダイエットを意識した不 適切な食事選択が行われる傾向にあり（6）, とりわけ青 年期に招ける食事の質は，精神的健康度に多大な影響 を及ぼす可能性が指摘されている為 (7)，特に問題にな 
ると考えられる。

日々の食事では, 様々な栄養素を含む多種多様な食品 が同時に摂取されている。よって単一の栄養素や食品で はなく，様々な栄養素が相互作用している事を考光，食 事パターンでとらえる事が近年は妥当とされている (8)。実際, 葉酸, ビタミン B, ビタミン C, n-3 系多価 不飽和脂肪酸, ビタミン $\mathrm{D}$, ビタミン $\mathrm{E}$, 野菜類, 魚類 といった特定の栄養素については，らつ症状との関連は 明らかにされていない(9)。

アメリカの成人女性に拈いて，「ヘルシー食パターン」 で The Patient Health Questionnaire (PHQ) によるうつ症 状のスコアが低かったことや (10), スペインの大学生 に敃いて「地中海式食事」を順守しているかを調べた「地 中海式食事順守指数」のアドヒアランスと Diagnostic and Statistical Manual of Mental Disorders（DSM-IV）によ るらつリスクが負の相関を示したことが報告されている (11)。またノルウェーの中学生に抮いて，「ノルウェー 食パターン」で Strengths and Difficulties Questionnaire （SDQ）による精神障害をもつ者が少なく，「ジャンク／ コンビニ食パターン」は多動性障害に関連していたとさ れ (12), 幼少期から青年期にかけての食事摂取パター ンと精神的健康度との関連が報告されている。

食事摂取パターンは居住地や社会, 文化と密接に関連 しており (15), 国や研究対象の年齢が異なれば食事摂 取パターンも大きく変わることが予想される。わが国に 打いては, 女子大学生について「和風扮惣菜食パターン」 が MOS 36-Item Short-Form Health Survey（SF-36）によ る「全体的健康感」及び「社会的生活機能」と有意な正 の相関を示した報告や (13), 中年層に拈いて「野菜・ 果物パターン」が「穀類の少量摂取傾向パターン」に比 べ有意に高いSF8 Health Survey（SF-8）による「全体的 健康感」の得点を示した報告があるが (14), 食事摂取 パターンと精神的健康度との関係については十分な研究 が行われていないのが現状である。

そこで, 我々は女子大学生を対象とし, 食物摂取状況 から食事摂取パターンを類型化し, 現在の食習慣や精神 的健康度との関連を検討した。

\section{方法}

\section{1. 調査対象者および調査方法}

2017 年 $6 \sim 7$ 月, 岡山県内の私立大学に通与食品栄 養学科の女子学生 $1 \sim 4$ 年生を対象に無記名自記式のア ンケート調査を行った。学生へ調査趣旨, 回答内容, 回 答拒否により不利益が生じないことなどを説明し，同意 を得た場合のみ回答するよう依頼し, 口頭にてイン フォームドコンセントを行った。また, アンケートの回 答をもって調査に同意したものとした。回答された質問 紙は当日回収し，320名に配布し 301 名から回答を得た。 有効回答率は $94.1 \%$ であった。

本調査はノートルダム清心女子大学に打ける「ヒトを
対象とする研究」に関する研究倫理審査委員会の承認を 得たらえで実施した。

\section{2. 調査内容}

アンケートの質問項目は，1）基本属性，2）現在の食 習慣，3）食物摂取状況，4）精神的健康度とした。

\section{1）基本属性}

学年，年齢，居住形態（家族と同居，他人と同居，寮 生活，1 人暮らし)，身長，体重について尋祇，身長及 び体重から BMI を算出した。

\section{2）現在の食習慣}

森脇ら（16）によるアンケートを参考に 12 項目のアン ケートを作成した。回答は「該当する」「やや該当する」 「あまり該当しない」「全く該当しない」または,「いつも」 「たいてい」「ときに」「いいえ」の４件法で，望ましい ものから 3 点, 2 点, 1 点, 0 点とし得点化した。

\section{3）食物摂取状況}

最近 $1 \sim 2$ 力月程度のらちの 1 週間を単位として，摂 取目安量と摂取頻度から食品群別摂取量・栄養素摂取量 を推定できる FFQg（Excel 栄養君・食物摂取頻度調査） の新 FFQg ver. 5 を用いた。菓子・嗜好飲料は食事バラ ンスガイドに颃いて料理として区分されない為除外し， その他の食物摂取状況から食事摂取パターンの分類を 行った。また，食事摂取パターン別の食品群別摂取量は $1,000 \mathrm{kcal}$ 当たりにエネルギ一調整を行い, 総エネルギー 量も割り出した。

\section{4）精神的健康度}

General Health Questionnaire の 28 項目短縮版 (GHQ-28) を用いた（17）。GHQ-28 では下位尺度として，身体的症 状，不安と不眠，社会的活動障害，らつ傾向が測定可能 である。

\section{3. 統計解析}

統計解析には SPSS Statistics Ver. 22.0 を使用した。 FFQg により得られた食品群別摂取量からの食事摂取パ ターンの類型化については, 先行研究を参考に K-means 法によるクラスター分析を行い，クラスター数を 3 個に 設定した（18）。食事摂取パターンと BMI，食品群別摂 取量，エネルギー量及び精神的健康度については，一元 配置分散分析を行い，多重比較にはチューキーの HSD 検定を用いた。食事摂取パターンと居住形態については ピアソンの $\chi^{2}$ 乗検定と調整残差から残差判定を行った。 食事摂取パターンと現在の食習慣については, クラスカ ル・ウォリス検定後, 有意になった項目についてマンホ イットニーのU 検定を行った。統計学的有意水準は $\mathrm{p}<$ 0.05 に設定した。

結果

1. 食物摂取状況からの食事摂取パターンについて

FFQg で得られた食品群別摂取量を用いてクラスター 
分析にて類型化した結果を表 1 に示す。クラスター 1 は 平成 28 年「国民健康・栄養調査」と比較し, どの食品 群についても $15 \sim 29$ 歳代の平均摂取量に近似していた
為, 「若者日本食パターン」と名付けた。クラスター 2 は平成 28 年「国民健康・栄養調査」の $15 \sim 29$ 歳代と 比較し, 摂取量が少ない食品群が多い為,「少食パターン」

表 1 食事摂取パターンとエネルギーと食品群別摂取量について

\begin{tabular}{|c|c|c|c|}
\hline & クラスター 1 & クラスター 2 & クラスター 3 \\
\hline 食事㠌取パターン & 若者日本食パターン & 少食パターン & 乳製品パターン \\
\hline 標本数 & 137 & 71 & 93 \\
\hline エネルギー（kcal） & $1,658.3 \pm 299.0$ & $\frac{\Gamma_{1,259.9 \pm 336.9}^{* *}}{{ }^{* *} \pm 33}$ & $\begin{array}{c}* * \\
\underbrace{* *} \\
1,805.1 \pm 393.5\end{array}$ \\
\hline BMI $\left(\mathrm{kg} / \mathrm{m}^{2}\right)$ & $20.2 \pm 1.9$ & $20.0 \pm 1.6$ & $20.4 \pm 2.1$ \\
\hline 穀類（めし，ゆで麺等）（g） & $\begin{array}{r}\text { } \\
400.6 \pm 71.7\end{array}$ & $\frac{\Gamma}{264.6 \pm 84.0}$ & $\begin{array}{c}\text { P }^{*} \\
344.5 \pm 88.9\end{array}$ \\
\hline い夕類（g） & $30.1 \pm 23.8$ & $18.5 \pm 19.7$ & $36.6 \pm 29.8$ \\
\hline 緑黄色野菜（g） & $74.5 \pm 35.7$ & $38.0 \pm 23.5$ & $7_{77.4 \pm 48.9}^{*}$ \\
\hline その他の野菜（きのこ類含む）（g） & $111.1 \pm 51.1$ & $54.9 \pm 33.4$ & $127.1 \pm 83.6$ \\
\hline 海藻類（g） & $2.9 \pm 2.9$ & $1.2 \pm 1.2$ & $2.9 \pm 2.7$ \\
\hline 豆類（g） & $45.3 \pm 34.4$ & $26.9 \pm 25.1$ & $\underbrace{* *}_{45.3 \pm 40.6}$ \\
\hline 魚介類（g） & $41.2 \pm 26.0$ & $22.3 \pm 21.3$ & $\underbrace{* *}+34.5 \pm$ \\
\hline 肉類 $(\mathrm{g})$ & $98.2 \pm 45.6$ & $65.0 \pm 43.4$ & $\begin{array}{c}* * \\
95.5 \pm 53.6\end{array}$ \\
\hline 卵類（g） & $37.2 \pm 16.2$ & $28.3 \pm 13.9$ & $\overbrace{40.9 \pm 2}^{* *} 22.2$ \\
\hline 乳類（g） & $90.7 \pm 43.8$ & $\frac{\Gamma}{88.3 \pm 56.0}$ & $\overbrace{225.0 \pm 65.6}^{*}$ \\
\hline 果実類（g） & $52.5 \pm 42.5$ & $21.6 \pm 22.1$ & ${ }^{*}{ }^{*} .0 \pm 71.1$ \\
\hline 菓子類（g） & $68.8 \pm 45.6$ & $\frac{\Gamma}{69.3 \pm 47.8}$ & $\begin{array}{c}* * \\
* * \\
95.6 \pm 65.7\end{array}$ \\
\hline 嗜好飲料（g） & $54.1 \pm 72.0$ & $\overline{100.6}^{* *} \pm 124.7$ & $56.3 \pm 68.6$ \\
\hline 砂糖・甘味料類（g） & $5.0 \pm 3.3$ & $3.7 \pm 3.6$ & ${ }_{5.6 \pm 3.6}^{*}$ \\
\hline 種実類（g） & $1.2 \pm 2.2$ & $1.2 \pm 3.2$ & $1.2 \pm 2.3$ \\
\hline 油脂類 $(\mathrm{g})$ & $11.0 \pm 4.9$ & $8.7 \pm 4.5$ & $D_{12.2 \pm 5.6}^{*}$ \\
\hline 調味料・香辛料類（g） & $26.8 \pm 17.5$ & $17.1 \pm 10.4$ & $2^{*}{ }^{*} .7 \pm 15.2$ \\
\hline
\end{tabular}

${ }^{*} \mathrm{p}<0.05, \quad * * \mathrm{p}<0.01 \quad$ (Tukey honestly significant difference test)

数値は平均值士標準偏差で示した。 
と名付けた。クラスター 3 は平成 28 年「国民健康・栄 養調査」の $15 \sim 29$ 歳代と比較し, 同等量程度を摂取し た食品群が多いが, 乳類の摂取が特に多い為, 「乳製品 パターン」と名付けた。

各食事撕取パターンの内訳をみると, 「若者日本食パ ターン」では穀類の摂取量 $(400.6 \pm 71.7 \mathrm{~g})$ が「少食パター ン $(264.6 \pm 84.0 \mathrm{~g}) 」$ 及び「乳製品パターン（344.5土 $88.9 \mathrm{~g}) 」$ に比べ, 有意に多かった $(\mathrm{p}<0.05)$ 。「少食パター ン」では, 穀類 $(264.6 \pm 84.0 \mathrm{~g}, \mathrm{p}<0.05)$, い子類 (18.5 $\pm 19.7 \mathrm{~g}, \mathrm{p}<0.05)$, 緑黄色野菜類 $(38.0 \pm 23.5 \mathrm{~g}, \mathrm{p}<0.01)$, その他野菜類 $(54.9 \pm 33.4 \mathrm{~g}, \mathrm{p}<0.01)$, 海藻類 $(1.2 \pm 1.2 \mathrm{~g}$,

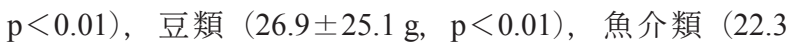
$\pm 21.3 \mathrm{~g}, \mathrm{p}<0.01)$ ，肉類 $(69.0 \pm 43.4 \mathrm{~g}, \mathrm{p}<0.01)$ ，卵 類 $(28.3 \pm 13.9 \mathrm{~g}, \mathrm{p}<0.01)$, 果実類 $(21.6 \pm 22.1 \mathrm{~g}, \mathrm{p}<$ $0.05)$, 砂糖・甘味料類 $(3.7 \pm 3.6 \mathrm{~g}, \mathrm{p}<0.05)$, 油脂類 (8.7 $\pm 4.5 \mathrm{~g}, \mathrm{p}<0.05)$, 調味料・香辛料類 $(17.1 \pm 10.4 \mathrm{~g}, \mathrm{p}$ <0.05）の摂取量が「若者日本食パターン」及び「乳製 品パターン」に比べ有意に少なかったが，嗜好飲料の摂 取量（100.6 $\pm 124.7 \mathrm{~g} ）$ は有意に多かった（ $\mathrm{p}<0.01)$ 。 た「乳製品パターン」では, 乳類 $(22.5 \pm 65.6 \mathrm{~g}, \mathrm{p}<0.05)$, 菓子類（95.6 $\pm 65.7 \mathrm{~g}, \mathrm{p}<0.01 ）$ の摂取量が，「若者日本 食パターン」及び「少食パターン」と比べ, 有意に多 かった。しかしながら，「若者日本食パターン（68.8土 $45.6 \mathrm{~g}) 」$ と「少食パターン $(69.3 \pm 47.8 \mathrm{~g}) 」$ でも平成 28 年「国民健康・栄養調査 $(29.4 \pm 45.3 \mathrm{~g}) 」$ と比較すると 菓子類の摂取量は 2 倍程の結果となっており，3つの食 事パターンともに菓子類の摂取量は多かった。

3つの食事摂取パターン別にエネルギーについて比較 すると，「乳製品パターン $(1,805.1 \pm 393.5 \mathrm{kcal}) 」$ 」若者 日本食パターン $(1,658.3 \pm 299.0 \mathrm{kcal}) 」$ 及び「少食パター ン $(1,259.9 \pm 336.9 \mathrm{kcal}) 」$ と比べ有意にエネルギーが多 く $(\mathrm{p}<0.01)$, また「少食パターン」では「若者日本食 パターン」及び「乳製品パターン」と比ベ有意にエネル ギーが少なかった（p<0.01）。BMIについては，3つの 食事摂取パターンの間で有意な差はみられなかった。

\section{2. 食事摂取パターンと基本属性との関連}

3つの食事摂取パターンと居住形態についての結果を
表 2 に示す。「若者日本食パターン」に拈いて，家族と 同居している者が有意に多く（調整済久残椬 $3.3 ）, 1$ 人 暮らしの者が少なかった（調整済久残椬－3.4）。また「少 食パターン」に揖いて, 1 人暮らしの者が有意に多く（調 整済み残渣 5.7), 家族と同居している者が少なかった（調 整済久残椬－5.6）。尚，「若者日本食パターン」，「少食 パターン」,「乳製品パターン」のらち, 各 2 名は居住状 態について未回答であった。

\section{3. 食事摂取パターンと現在の食習慣との関連}

3つの食事摂取パターンと現在の食習慣についての結 果を表 3 に示す。「少食パターン」では, 「若者日本食パ ターン」及び「乳製品パターン」に比べ，「朝食を一緒 に食べる人がいる $(\mathrm{p}<0.01) 」, 「$ 夕食を一緒に食べる人 がいる $(\mathrm{p}<0.01) 」, 「$ 栄養バランスを考㝋ている（p< $0.01) 」 の$ 得点が有意に低かった。その他の項目につい ては食事摂取パターン別で有意な差はみられなかった。

\section{4. 食事摂取パターンと精神的健康度との関連}

3 つの食事摂取パターンと GHQ-28 の結果を表 4 に示 す。「乳製品パターン $(1.2 \pm 1.8) 」$ は若者日本食パター ン $(0.7 \pm 1.2) 」 に$ に比べ，「不安と不眠」の得点が有意に 高かった $(\mathrm{p}<0.05)$ 。その他の項目については食事摂取 パターン別で有意な差はみられなかった。

\section{考察}

\section{1. 食事摂取パターンと食品群別摂取量の関連}

「若者日本食パターン」では穀類の摂取量が，他の食 事摂取パターンと比べ多かったが, 平成 28 年「国民健康・ 栄養調査」と比較すると同程度であった為,「少食パタ一 ン」と「乳製品パターン」で穀類の摂取量が少ないと考 えられる。また，エネルギーも平成 28 年「国民健康・ 栄養調査」と比較すると同程度であり,「若者日本食パ ターン」は，この年代の代表的な食事パターンであると 考学らる。

「少食パターン」では, 穀類, いも類, 緑黄色野菜類, その他野菜類, 海藻類, 豆類, 魚介類, 肉類, 卵類, 果

表 2 食事摂取パターンと居住形態の関連について

\begin{tabular}{|c|c|c|c|c|c|}
\hline & & $\begin{array}{c}\text { 若者日本食パターン } \\
(\mathrm{n}=135)\end{array}$ & $\begin{array}{c}\text { 少食パターン } \\
(\mathrm{n}=69)\end{array}$ & $\begin{array}{c}\text { 乳製品パターン } \\
\quad(\mathrm{n}=91)\end{array}$ & $\chi^{2}$ \\
\hline \multirow{2}{*}{ 家族と同居 } & & $87.4 \%$ & $55.1 \%$ & $84.6 \%$ & \multirow{6}{*}{$\begin{array}{c}33.7 \\
(\mathrm{p}<0.01)\end{array}$} \\
\hline & 調整済み残椬 & $3.3^{*}$ & $-5.6^{*}$ & 1.6 & \\
\hline \multirow{2}{*}{ 寮生活 } & & $0.7 \%$ & $0 \%$ & $0 \%$ & \\
\hline & 調整済み残椬 & 1.1 & -0.6 & -0.7 & \\
\hline \multirow{2}{*}{1 人暮らし } & & $11.9 \%$ & $44.9 \%$ & $15.4 \%$ & \\
\hline & 調整済み残椬 & $-3.4^{*}$ & $5.7^{*}$ & -1.5 & \\
\hline
\end{tabular}

*調整済み残椬の絶対値>1.96

「若者日本食パターン」,「少食パターン」,「乳製品パターン」のらち, 各 2 名は居住状態について未回答であった。 
表 3 食事摂取パターンと現在の食習慣について

\begin{tabular}{lccc}
\hline & 若者日本食パターン & 少食パターン & 乳製品パターン \\
\hline 食事を楽しく食べている & $2.5 \pm 0.7$ & $2.4 \pm 0.8$ & $2.7 \pm 2.2$ \\
食事時刻は決まっている & $1.5 \pm 0.8$ & $1.3 \pm 1.0$ & $1.5 \pm 0.9$ \\
朝食を一緒に食べる人がいる & $0.9 \pm 0.9$ & $0.5 \pm 0.7$ & $0.9 \pm 0.9$ \\
昼食を一緒に食べる人がいる & $2.3 \pm 0.9$ & $2.3 \pm 0.7$ & $2.3 \pm .0 .8$ \\
夕食を一緒に食べる人がいる & $1.8 \pm 0.9$ & $1.3 \pm 0.9$ & $1.8 \pm 1.0$ \\
市販の弁当や総菜類なぞを利用する & $1.3 \pm 0.8$ & $1.1 \pm 0.8$ & $1.2 \pm 0.8$ \\
塩分を控えている & $1.4 \pm 0.7$ & $1.2 \pm 0.7$ & $1.3 \pm 0.7$ \\
栄養バランスを考えている & $1.9 \pm 0.7$ & $1.5 \pm 0.7$ & $1.9 \pm 0.7$ \\
よくかんで食べている & $1.9 \pm 0.7$ & $1.5 \pm 0.7$ & $1.9 \pm 0.7$ \\
栄養成分表示を活用している & $1.2 \pm 1.0$ & $1.0 \pm 0.9$ & $1.2 \pm 0.9$ \\
好き嫌いが多い & $2.1 \pm 1.0$ & $1.9 \pm 0.9$ & $2.0 \pm 0.9$ \\
外食を利用する & $1.2 \pm 0.7$ & $1.1 \pm 0.8$ & $1.3 \pm 0.7$ \\
\hline
\end{tabular}

${ }^{*} \mathrm{p}<0.05, \quad * * \mathrm{p}<0.01 \quad$ (Kruskal-Wallis and Mann-Whitney U tests)

数值は平均值土標準偏差で示した。

表 4 食事摂取パターンと精神的健康度の関連について

\begin{tabular}{lccc}
\hline & 若者日本食パターン & 少食パターン & 乳製品パターン \\
\hline GHQ 総合得点 & $5.9 \pm 4.0$ & $5.5 \pm 3.5$ & $6.6 \pm 5.5$ \\
身体的症状 & $1.0 \pm 1.4$ & $1.0 \pm 1.3$ & $1.0 \pm 1.3$ \\
不安と不眠 & $0.7 \pm 1.2$ & $0.8 \pm 1.0$ & $1.2 \pm 1.8$ \\
社会的活動障害 & $3.7 \pm 1.9$ & $3.6 \pm 2.0$ & $3.8 \pm 2.0$ \\
うつ傾向 & $0.4 \pm 1.2$ & $0.2 \pm 0.6$ & $0.5 \pm 1.3$ \\
\hline
\end{tabular}

$* \mathrm{p}<0.05$ (Tukey honestly significant difference test)

数值は平均值士標準偏差で示した。

実類, 砂糖 - 甘味料類, 油脂類, 調味料 - 香辛料類の摂 取量が他の $2 つ 0$ 食事摂取パターンと比べ少なかった。 「少食パターン」で摂取量が少なかった食品群は, 平成 28 年「国民健康・栄養調査」と比較しても摂取量が少 なく栄養素の不足が予測される。エネルギーも他の食事 摂取パターンに比べ「少食パターン」で少なかったが, BMI については3つの食事摂取パターンの間で差が認 められなかった。そこで，現在「食事時刻が決まってい る」との質問に対し, 食事摂取パターンとの関係をみた ところ，「少食パターン」では「全く該当しない」と答 えた者の割合が有意に高く，このことから「少食パター ン」では, 食事時間が不規則になっている可能性が考兄 られる（19）。また，菓子類や嗜好飲料などの間食をし ている可能性も考兄られ, 実際, 嗜好飲料（本研究では ジュース類のみ対象）は「少食パターン」で他の 2 つ
食事摂取パターンに比べ摂取量が有意に多かった。他方, 本研究では消費エネルギーについてまで調査は行ってい ないが，対象者が女子学生であり，大差はないものと考 えられる。

また「乳製品パターン」では，乳類，菓子類の摂取量 が他の食事パターンと比べて多く, 平成 28 年「国民健康・ 栄養調査」と比較しても摂取量が多かった。エネルギー

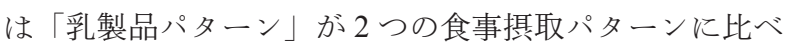
多くはなっているものの，平成 28 年「国民健康・栄養 調査」と同程度であり，前述の通り BMI についても 3 つの食事摂取パターンで差がなかった。「乳製品パター ン」では, 穀類の摂取が「若者日本食パターン」と比較 して少なく, 穀類のかわりに乳類・菓子類からエネルギー を摂取していることが考えられる。 


\section{2. 食事摂取パターンと基本属性との関連}

「若者日本食パターン」では家族と同居の者が多く,「少 食パターン」では，1 人暮らしの者が多かった。高校生， 大学生の男女を対象に食事の内容 - 食事状況について比 較した先行研究に拈いても, 同様の結果が報告されてい る(20)。しかしながら, 本研究の対象者は女子学生の みであった為, 家族と同居しバランスが考えられた食事 が提供されていても, 菓子類の摄取量が多い傾向にあっ たものと考光られる。さらに 1 人暮らしになると食事が 扔ろそかになり，菓子類や嗜好飲料からエネルギーを摂 取する割合が多くなると考えられる。

\section{3. 食事摂取パターンと現在の食習慣との関連}

「少食パターン」では,「朝食を一緒に食べる人がいる」， 「夕食を一緒に食べる人がいる」の得点が低かった。「少 食パターン」に拉いて，1 人暮らしをしている割合が多 かったことから，朝食・夕食は 1 人で食べている人が多 いと考えられる。また，「少食パターン」で「栄養バラ ンスを考えている」の得点が低かった。先行研究に颃い て，健康食パターンについての関心の低さと，1 人暮ら しである事が有意に関連していたことが報告されて拉り (21)，本研究でも同様の結果が得られた。

\section{4. 食事摂取パターンと精神的健康度との関連}

「乳製品パターン」で不安と不眠の点数が高かった。「乳 製品パターン」は乳類・菓子類からの摂取が多い食事パ ターンであり, 糖質や脂質が多い食事パターンと考兄ら れる。本研究と似た食事パターンが抽出されているイギ リスの中年層を対象に行われた研究では, 甘い菓子, チョ コレート, 揚げ物, 加工肉, 精製された穀物, 高脂質の 乳製品を高頻度に摂取する「加工食品パターン」で Center for Epidemiologic Studies Depression (CES-D) に よるらつ傾向得点が有意に高かったことが報告されてお り (22), 菓子類と高脂質の乳製品の高頻度の摂取は精 神的健康度に影響を及ぼす可能性が考兄られる。

一方で，日本の大学生に打いて牛乳・乳製品の低摂取 頻度群で University Personality Inventory（UPI）を用いて 評価した精神的健康度が低い傾向にあるとの報告や (5), 日本の女子大学生に挏いてヨーグルトの摂取頻度 が CES-D 高得点群で有意に低かったものの乳類の摂取 頻度については有意差がなかったとの報告がある（23）。 またスペインの成人に扣いて，ヨーグルトの習慣的摂取 が精神的健康度を含む健康指標 Health-related quality of lifeの改善に関係しなかったことが報告されている (24)。乳類及び乳製品ではカテゴリーが広く，低脂質の ものもあれば高脂質のものもあり，精神的健康度に影響 を及济す可能性に差異があるものと考光られる。本研究 でも乳類の中で分類を行っていない為, 牛乳やヨーグル 卜等どのような乳製品が多く摂取されているかについて は今後検討が必要である。

菓子類については，南ブラジルの妊婦において PHQ
により評価されたらつ障害に菓子・砂糖の高頻度の摂取 が有意に関係していることや (25)，スペインの中学生 に拈いて情動症状のある女性に菓子・脂質の高摂取パ ターンの人が有意に多かったこと（26），またドイッ， ポーランド，ブルカリアの女子学生に拈いて菓子類や ファーストフードの摂取が Cohen's Perceived Stress Scale (PSS) によるストレスの自覚スコアと関係していたこ とが報告されている（27）。またイギリスの大学生に拈 いて菓子類・ファーストフードの摂取が PSS によるス トレスの自覚スコア及び modification of the Beck Depression Inventory（M-BDI）によるらつ症状スコアと正の相 関を示したとの報告もある $(28)$ 。これらのことから菓 子類の摂取と精神的健康度との間には関連があることが 考えられる。

これらの研究では食品群別の摂取頻度で食事摂取パ ターンを分類しており，食品群別に摂取量を検討し食事 摂取パターンを分類した本研究と比較するのは難しい。 しかしながら本研究において，「乳製品パターン」は, 他の 2 つの食事摂取パターンより乳類及び菓子類からの 摂取エネルギーが有意に多くなって拈り，女子学生に括 いて不安と不眠の点数が高かったことには, 乳類及び菓 子類の過㮃摂取が関係している可能性が考えられる。

一方，アメリカの中年女性に扎いて PHQ によるらつ 症状は高カロリ一の甘い菓子とは正の相関を示したもの の, 高カロリーの甘くない菓子とは負の相関を示したこ とや (29), 日本の大学生に拈いて UPI と菓子類との間 に有意な関係がなかったことが報告されており（5），菓 子類の種類によっても精神的健康度への影響に差がある ものと考光られ。

本研究に扣いて, 平成 28 年「国民健康・栄養調査」 とほぼ同様の摂取量を示していた「若者日本食パターン」 に拈いて，不安と不眠の点数が低かった。いくつかの先 行研究に扣いて，青年期の良い精神的健康状態は果物・ 野菜・魚がバランスよく摂取できるような食事パターン と関連しているとされ（12）, 日本食パターンはこのよ らな食事パターンと共通するところがある。日本の成人 を対象とした研究では，野菜・きのこ類・魚介類を多く 摂取し，豆腐・肉類をバランスょく摂取しているグルー プで日本語版気分・不安障害調査票（K6）のスコアが 有意に低かったことや (30)，野菜・果物・大豆製品・ きのこ・緑茶を高頻度に摂取しているグループで CES-D の得点が低かったこと（9）が報告されており，従来から 続く日本食パターンの食事，すなわち米と野菜と魚介類 を中心とした和食を摂取している人は，良い精神的健康 状態にあると考えられ，本研究に抏いても同様の結果が 得られたと考光る。

青年期に拈ける食事の質は，精神的健康度に影響を及 ぼすことが指摘されているが，本研究に拈ける「若者日 本食パターン」については, 現在の食習慣, 精神的健康 状態について大きな問題はないものの，菓子類の摂取量 が多い為, 栄養素の偏りや過剰に注意を促す必要がある。 
「少食パターン」では栄養学を学んでいる学生であって も栄養バランスについて興味がなく, 菓子類や嗜好飲料 からのエネルギー摂取が多い状態にあり, 精神的健康状 態について大きな問題は今のところないものの, 今後こ の生活を継続していくことは避ける必要があるため, バ ランスのとれた食事からエネルギーを摂取するよら働き かけていく必要がある。また,「乳製品パターン」では 乳類や菓子類の過㮃摂取があり，精神的健康度に影響を 及ぼしている可能性がある。そのため乳類の選び方や， 菓子類の摂取自体を控えるよう指導していく必要があ る。これらの食事指導により女子学生の食生活を改善す れば, 将来にわたって精神的健康度を改善することにつ ながるのではないかと考える。

\section{5. 本研究の限界}

本研究は自記式アンケートによる調査であった為, 特 に FFQg について過大申告や過少申告の可能性が考えら れる。しかしながら, 学生では FFQg と 7 日間食事記録 法による栄養素摂取量の相関が一般成人に比べて高くな ることが報告されて招り（31），FFQgの信頼性には専門 知識の有無が影響するものと考兄られる。本研究の対象 者は全て食品栄養学科の学生であり, FFQg の質問表に 扣けるポーションサイズの把握など一般の対象者に比べ 優孔ていると考光られるが, 今後, 食物や栄養について なじみのない一般の人を対象とする場合は，フードモデ ルを活用することや，食生活状況を聞き取りながら行ら など，ポーションサイズや頻度の正確な聞き取りが必要 であると考える。

\section{利益相反なし}

\section{文献}

( 1 ) https://www.mhlw.go.jp/bunya/kenkou/eiyou/h28-houkoku. html (2018.8.1)

(2) https://www.mhlw.go.jp/toukei/saikin/hw/k-tyosa/ktyosa16/index.html (2018.8.1)

(3) Merikangas KR, He JP, Burstein M, Swanson SA, Avenevoli S, Cui L, et al. Lifetime prevalence of mental disorders in U.S. adolescents: results from the National Comorbidity Survey Replication-Adolescent Supplement (NCS-A). J Am Acad Child Adolesc Psychiatry 2010; 49(10):980-989.

( 4 ) O'Neil A, Quirk SE, Housden S, Brennan SL, Williams LJ, Pasco JA, et al. Relationship between diet and mental health in children and adolescents: a systematic review. Am J Public Health 2014;104(10):e31-42.

（5）富永美穂子, 清水益治, 森 敏昭, 兒玉憲一, 佐藤一 精. 中・高生扔よび大学生の食生活を中心とした生活 習慣と精神的健康度の関係. 日本家政学会誌 2001; 52(6):499-510.

(6) Jacka FN, Kremer PJ, Leslie ER, Berk M, Patton GC, Toumbourou JW, et al. Associations between diet quality and depressed mood in adolescents: results from the Australian Healthy Neighbourhoods Study. Aust N Z J Psychiatry 2010;44(5):435-442.

( 7 ) Jacka FN, Kremer PJ, Berk M, de Silva-Sanigorski AM, Moodie M, Leslie ER, et al. A prospective study of diet quality and mental health in adolescents. PLoS One 2011; 6(9):e24805.

( 8 ) Hu FB. Dietary pattern analysis: a new direction in nutritional epidemiology. Curr Opin Lipidol 2002;13(1):3-9.

(9) Nanri A, Kimura Y, Matsushita Y, Ohta M, Sato M, Mishima N, et al. Dietary patterns and depressive symptoms among Japanese men and women. Eur J Clin Nutr 2010;64(8):832-839.

(10) Kim WK, Shin D, Song WO. Are dietary patterns associated with depression in U.S. adults? J Med Food 2016; 19(11):1074-1084.

(11) Sánchez-Villegas A, Delgado-Rodríguez M, Alonso A, Schlatter J, Lahortiga F, Serra Majem L, et al. Association of the Mediterranean dietary pattern with the incidence of depression: the Seguimiento Universidad de Navarra/ University of Navarra follow-up (SUN) cohort. Arch Gen Psychiatry 2009;66(10):1090-1098.

(12) Oellingrath IM, Svendsen MV, Hestetun I. Eating patterns and mental health problems in early adolescence - a cross-sectional study of 12-13-year-old Norwegian schoolchildren. Public Health Nutr 2014;17(11):2554-2562.

（13）小西香苗，百武愛子，村松 宰. 女子大学生に打忷る 食事パターンと健康関連 QOL との関連. 信州公衆衛 生雑誌 2013;7(2):83-94.

(14) Toyomaki A, Koga M, Okada E, Nakai Y, Miyazaki A, Tamakoshi A, et al. The relationship between a low grain intake dietary pattern and impulsive behaviors in middle-aged Japanese people. PLoS One 2017;12(7):e0181057.

(15) Murakami K, Sasaki S. Dietary intake and depressive symptoms: a systematic review of observational studies. Mol Nutr Food Res 2010;54(4):471-488.

（16）森脇弘子，岸田典子，上村芳枝，竹田範子，佐久間章 子, 寺岡千恵子, 他. 女子学生の健康状況・生活習慣・ 食生活と小学生時の食事中の楽しい会話との関連. 日 本家政学会誌 2007;58(6):327-336.

(17) Goldberg DP. (中川泰彬, 大坊郁夫訳) 日本版 GHQ : 精神健康調査票：手引。東京：日本文化科学社, 2013.

（18）中島順一. クラスター分析による食物摂取パターン分 析. 岐阜市立女子短期大学研究紀要第 57 輯 2008;4951.

(19) Berg C, Lappas G, Wolk A, Strandhagen E, Torén K, Rosengren A, et al. Eating patterns and portion size associated with obesity in a Swedish population. Appetite 2009; 52:21-26

（20）中山文子，藤岡由美子．大学生の食事を主とした生活 習慣と精神的健康に関する研究 : 高校生との比較を通 して. 松本大学紀要研究 2011:139-153.

(21) Motohashi K, Kaneko Y, Fujita K, Motohashi Y, Nakamura A. Interest in dietary pattern social capital, and psychological distress: a cross-sectional study in a rural Japanese community. BMC Public Health 2013;13:933. 
(22) Akbaraly TN, Brunner EJ, Ferrie JE, Marmot MG, Kivimaki M, Singh-Manoux A. Dietary pattern and depressive symptoms in middle age. Br J Psychiatry 2009;195(5): 408-413.

(23) 阿部由紀子. 大学生に打ける抑らつ傾向と食品摂取頻 度との関連性. 栄養学雑誌 2016;74(2):29-37.

(24) Lopez-Garcia E, Leon-Muñoz L, Guallar-Castillon P, Rodríguez-Artalejo F. Habitual yogurt consumption and health-related quality of life: a prospective cohort study. J Acad Nutr Diet 2015;115(1):31-39.

(25) Paskulin JTA, Drehmer M, Olinto MT, Hoffmann JF, Pinheiro AP, Schmidt MI, et al. Association between dietary patterns and mental disorders inpregnant women in Southern Brazil. Rev Bras Psiquiatr 2017;39(3):208-215.

(26) Aparicio E, Canals J, Voltas N, Valenzano A, Arija V. Emotional symptoms and dietary patterns in early adolescence: a school-based follow-up study. J Nutr Educ Behav 2017; 49(5):405-414.

(27) Mikolajczyk RT, El Ansari W, Maxwell AE. Food consumption frequency and perceived stress and depressive symptoms among students in three European countries. Nutrition Journal 2009;8:31.

(28) El Ansari W, Adetunji H, Oskrochi R. Food and mental health: relationship between food and perceived stress and depressive symptoms among university students in the United Kingdom. Cent Eur J Public Health 2014;22(2):9097.

(29) Jeffery RW, Linde JA, Simon GE, Ludman EJ, Rohde P, Ichikawa LE, et al. Reported food choices in older women in relation to body mass index and depressive symptoms. Appetite 2009;52(1):238-240.

(30) Suzuki T, Miyaki K, Tsutsumi A, Hashimoto H, Kawakami N, Takahashi M, et al. Japanese dietary pattern consistently relates to low depressive symptoms and it is modified by job strain and worksite supports. J Affect Disord 2013; 150(2):490-498.

（31）高橋啓子，吉村幸雄，開元多恵，國井大輔，小松龍史, 山本 成. 栄養素抢よび食品群別摂取量推定のための 食品群をべースとした食物摂取頻度調査の作成执よ び妥当性. 栄養学雑誌 2001;59(5):221-232. 